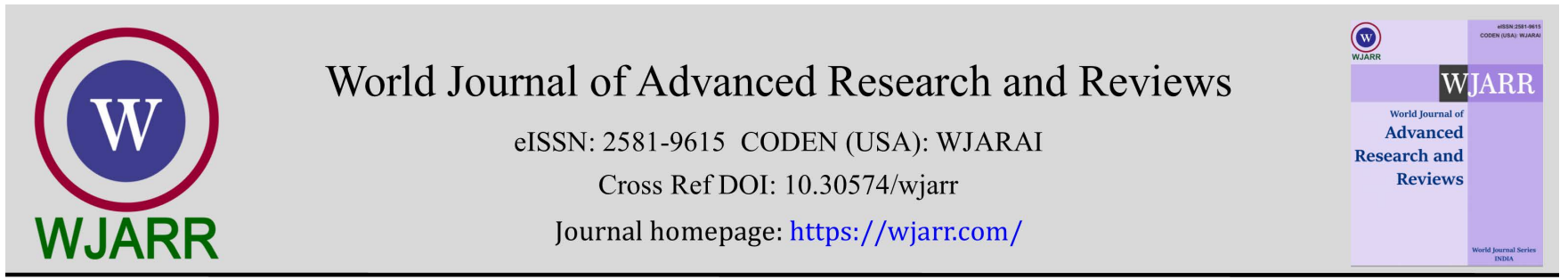

(RESEARCH ARTiClE)

Check for updates

\title{
Effects of aqueous leaf extract of Corchorus olitorius on the testis and blood testosterone level of adult Wistar rats
}

\author{
Godwin Chinedu Uloneme 1, ${ }^{*}$, Demian Nnabuihe Ezejindu ${ }^{2}$, Darlington Cyprian Akukwu ${ }^{1}$, Amadi Chibundu \\ Chiekezie $^{1}$ \\ ${ }^{1}$ Department of Anatomy \& Neurobiology, Faculty of Basic Medical Sciences, Imo State University, Owerri, Nigeria. \\ ${ }^{2}$ Department of Anatomy, Faculty of Basic Medical Sciences, Nnamdi Azikiwe University, Nnewi Campus, Anambra State, \\ Nigeria.
}

World Journal of Advanced Research and Reviews, 2021, 10(02), 024-030

Publication history: Received on 18 March 2021; revised on 25 April 2021; accepted on 27 April 2021

Article DOI: https://doi.org/10.30574/wjarr.2021.10.2.0186

\begin{abstract}
Background: The extract of Corchorus olitorius has a reasonable content of vitamins A and C, calcium, iron and fibre, and therefore enjoys a universal application in the treatment of some disease conditions, even as the whole leaf is a very important component of food in so many cultures.
\end{abstract}

Purpose: The study was designed to investigate the effect of Corchorus olitorius extracts on the testis of adult Wistar rats.

Method: A total number of thirty two adult Wistar rats weighing between 180 and 200 grammes separated into four groups labeled A,B,C and D respectively were used for the study. Animals in group A which served as the control group were fed with the normal rat chow and water only. The group B rats were administered $100 \mathrm{mg} / \mathrm{kg}$ body weight of aqueous extract of Corchorus olitorus; while those in group C were administered $500 \mathrm{mg} / \mathrm{kg}$ body weight of the extract. The group D rats received $1000 \mathrm{mg} / \mathrm{kg}$ body weight of the extract. For a period of four weeks, the different experimental animal groups received the respective aforementioned treatments once daily, around nine- o'clock in the morning through oral intubation. At the end of the 28 day treatment, the animals were sacrificed and the testes harvested for histological, investigation, and through cardiac puncture, blood samples for some hormonal studies was also collected and investigated using standard laboratory standards.

Results: Observations made showed that the extract produced no histological distortions, degenerative or defective effects on the testicular tissues. The testosterone levels of group B, C, and D rats were observed to be significantly higher $(\mathrm{P}<0.005)$ than that of the group A (control group).

Keywords: Corchorus olitorius; Sperm; Testis; Testosterone; Wistar Rats.

\section{Introduction}

The plant, Corchorus olitorius, widely grown in the tropics belongs to the family of Tiliaceae, and according to Matsufuji et al, (2001) [1], it has a high content of vitamin A and C, calcium, iron and fiber. In the Yoruba tribe of Nigeria, where it is called Ewedu, the leaves are used to prepare fresh soup and stew both in fresh and dried form (Tindall, 1983) [2]. Oke (1968) [3], in his analysis, stated that the plant on average, contains 85-87 H20, 1.5mg fiber, 4-8mg Fe, 250-266mg Ca, $0.3 \mathrm{mg}$ riboflawin, $0.1 \mathrm{mg}$ thiamine, and about $5 \mathrm{~g}$ carbohydrate. According to Ndlovu and Afolayan (2008) [4], the roots

${ }^{*}$ Corresponding author: Godwin Chinedu Uloneme

Department of Anatomy \& Neurobiology, Faculty of Basic Medical Sciences, Imo State University, Owerri, Nigeria.

Copyright $(2021$ Author(s) retain the copyright of this article. This article is published under the terms of the Creative Commons Attribution Liscense 4.0. 
and leaves of Corchorius olitorius are eaten as herbal medicine in South East Asia. In Nigeria and some other West African countries, the leaves which are mucilaginous are used as food vegetables Zakaria et al, (2006) [5] aimed at treating iron and folic acid deficiency. Aiyeloja and Bello (2006) [6] had reported that the leaves act as blood purifier. The leaf twigs are also believed to possess healing effects against heart problems Osuchukwu and Okeke, (2004) [7]. In their work, Duke and Wain (1981) [8] asserted that the plant products are demulcent, exhibiting rapid soothing effects, galactagogue in action, deobstruent, diuretic and antipyretic. The aqueous extract of Corchorius olitorius has also been demonstrated to posses Opioid-mediated anti-nociceptive action Zakari et al, (2005) [9]. Gupta et al (2003)[10] reported that the methanolic extracts of the plants has anti-convulsive property, while its leaf extract has been shown to reduce elevation of postprandial blood glucose levels in both rats and humans Innami et al, (2005)[11]

From the aforegoing, it could be understood that there is a pronounced indiscriminate and high consumption rate of the plant products, especially the leaves for several purposes ranging from therapeusis to curative activities, and most largely for dietetic and nutritional reasons. As a matter of fact, there is at present, very little information on the effect of Corchorius olitorius on the male gonad, where gamatogenesis takes place, neither is there at hand much information on the effect of the plant on the male sex hormones blood levels, especially, testosterone that plays a very important role in male fertility. This study therefore aims at investigating and unraveling the possible effects of aqueous extract of Corchorus olitorius on the microscopic anatomy of the tesistis and blood testosterone levels.

\section{Material and methods}

\subsection{Experimental Animals}

Thirty two adult Wistar rats weighing between 180 and 200g bred in the animal house of Anatomy \& Neurobiology Department, Faculty of Basic Medical Science, Imo State University, Owerri were used for this study. The animals were separated into four groups and housed in four separate cages marked A, B, C, and D respectively. The group A animals constituted the control group, while group B, C, and D formed the experimental groups. The rats were made to have free access to feed and water before and during the experimentation that lasted for twenty eight (28) days.

\subsection{Preparation of leaf extract}

About two weeks before housing the rats in separate cages for the experimentation proper, fresh leaves of Corchorus olitorius were harvested from a local farm and air-dried. The dried leaves were then ground into powdered form. The powder was then macerated in distilled water in 1:2wt/vol ratio and hours later, the filtrate was dried into a gel-like form with an oven and stored in readiness for administration to the rats.

\subsection{Administration of extract}

The group B rats were administered $100 \mathrm{mg} / \mathrm{kg}$ body weight $(0.8 \mathrm{ml})$ of Corchorus olitorius of the aqueous extract. The groups $\mathrm{C}$ and $\mathrm{D}$ rats received $100 \mathrm{mg} / \mathrm{kg}$ body weight $(1.8 \mathrm{mls})$ and $1000 \mathrm{mg} / \mathrm{kg}$ body weight (2.8mls) of the extract respectively, all through oral intubation.

Group A (control) received only water and normal rat chow.

\subsection{Collection of sample}

At the end of the twenty eight day treatment, the different animal groups were anaesthetized using chloroform vapour. Blood samples were collected from the animals via the popular cardiac puncture. The blood samples were each labeled according to the group they belonged to, and taken to the chemical pathology Department of a diagnostic laboratory where the hormone assay was carried out to ascertain their testosterone levels. The testes of the different animal groups were also harvested almost simultaneously with blood sample collection and stored in $10 \%$ normal saline and taken to the histology laboratory of Anatomy \& Neurobiology Department, Imo State University, where they were examined, weighed, and then subjected to normal tissue processing procedures.

\subsection{Histological Processing}

Some 48 hours after fixing, the tissues were put into graded alcohols which include 70\%, 80\%, 90\%, 95\%, and then absolute alcohol for an hour each. This was done to ensure the tissue samples were properly dehydrated before passing them through two changes of xylene in which they passed one hour each in xylene I and xylene II respectively. The xylene served as the clearing agent to prepare the tissues for immersion in two changes of wax bath for two hours each in a hot air oven. 
This was followed by infiltration carried out in molten paraffine wax at temperature of $60^{\circ} \mathrm{C}$ for two hours each in two changes. Using the rotary microtome, the embedded tissues were then sectioned and stained with the Haematoxylene and eosin method.

\subsection{Histological Evaluation}

The tissue sections produced were viewed one after the other under the microscope at various magnifications for clarity purposes, and the photomicrographs of the sections were produced, studied and interpreted.

\subsection{Statistical Analysis}

Statistical analysis of the data generated was done using the one-way SPSS window version 21.0 software. The results are presentated as mean and standard error of mean. Analysis of variant (ANOVA) was used in comparing differences within groups where values were declared significant at $\mathrm{p}<0.05$.

\section{Results and discussion}

Table 1 Effect of Aqueous Leaf Extract of Corchorus olitorius on Blood Testosterone Level.

\begin{tabular}{|l|l|l|l|l|}
\hline \multirow{2}{*}{ Group } & \multicolumn{2}{|l|}{ Testosterone (ng/ml) } & \multirow{2}{*}{ P value } & \multirow{2}{*}{ F value } \\
\cline { 2 - 5 } & MEAN & \pm SEM & & \\
\hline Group A & 2.30 & \pm 0.12 & 0.000 & \\
\hline Group B & 4.30 & \pm 0.12 & $0.000^{*}$ & \\
\hline Group C & 5.12 & \pm 0.28 & $0.000^{*}$ & 46.65 \\
\hline Group D & 4.82 & \pm 0.07 & $0.000^{*}$ & \\
\hline
\end{tabular}

The result in table I above shows that there was a significant increase in blood testosterone level of group B (4.30 \pm 0.12$)$; group C (5.12 \pm 0.28$)$; and group D (4.82 \pm 0.07$)$ when compared to group A rat $(2.30 \pm 0.12)$.

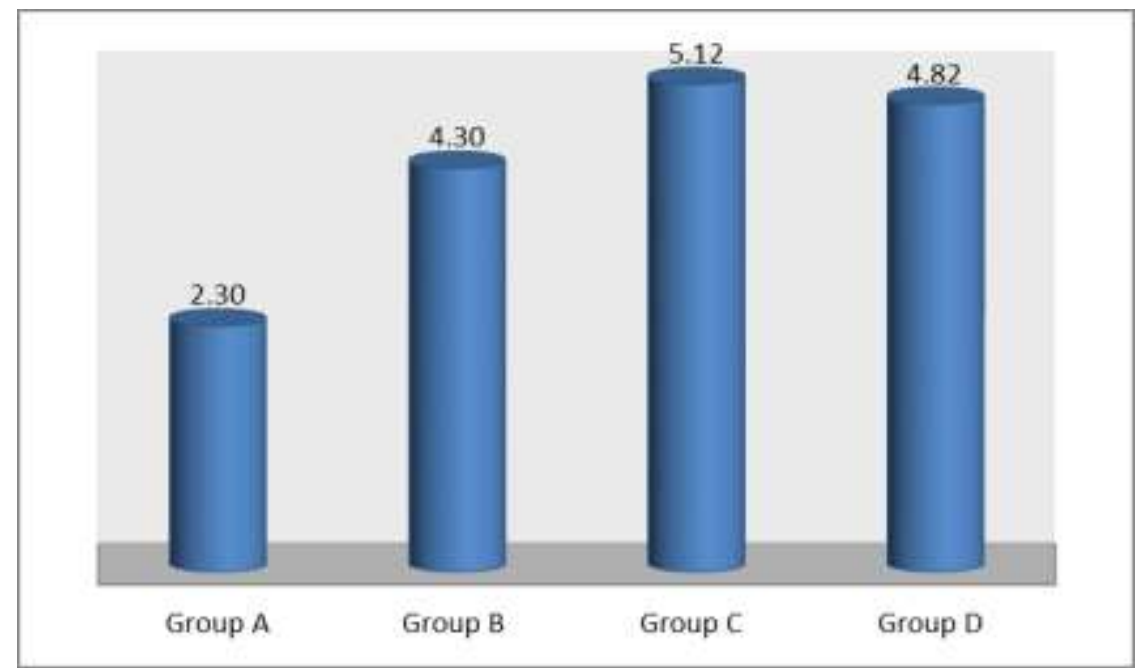

Figure 1 Bar Chat showing the effect of Corchorus olitorius on blood testosterone level. 


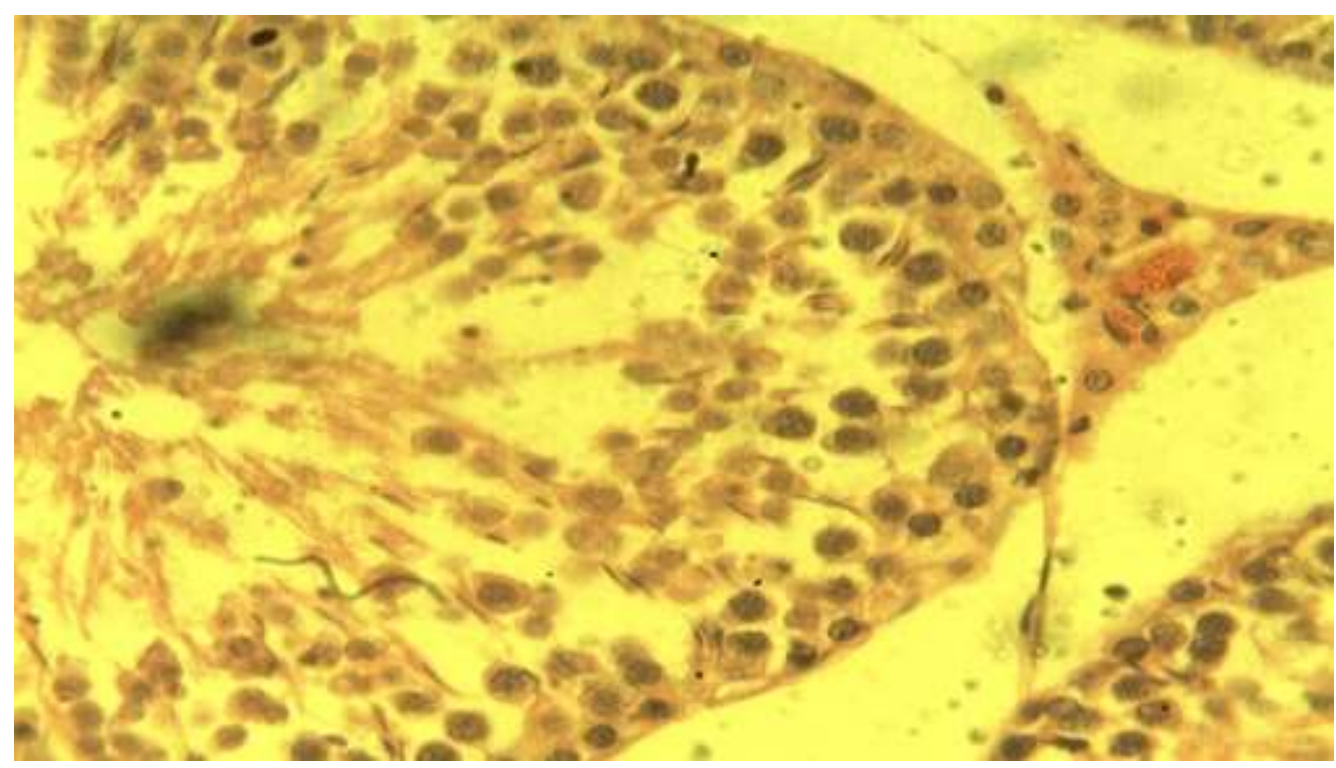

Figure 2 Representative photomicrograph of the testis from group A (control); seminiterous tubules (ST) and interstitium containing the Leydig cells are all normal. (X400:H\&E)

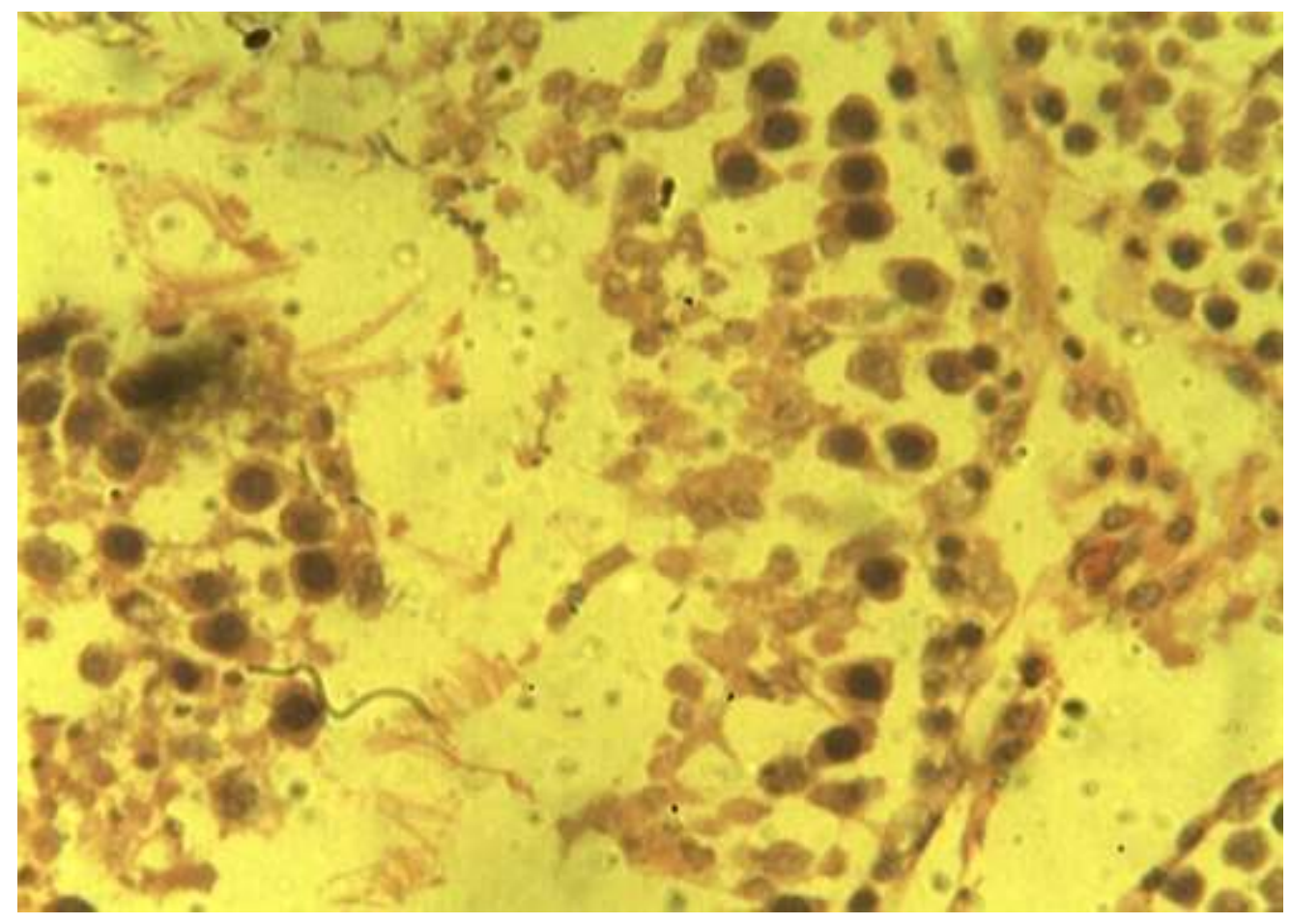

Figure 3 Photomicrograph of the testis from group B animals. The semiferious tubules and the interstitium are all intact and appear normal. (X400: H\&E). 


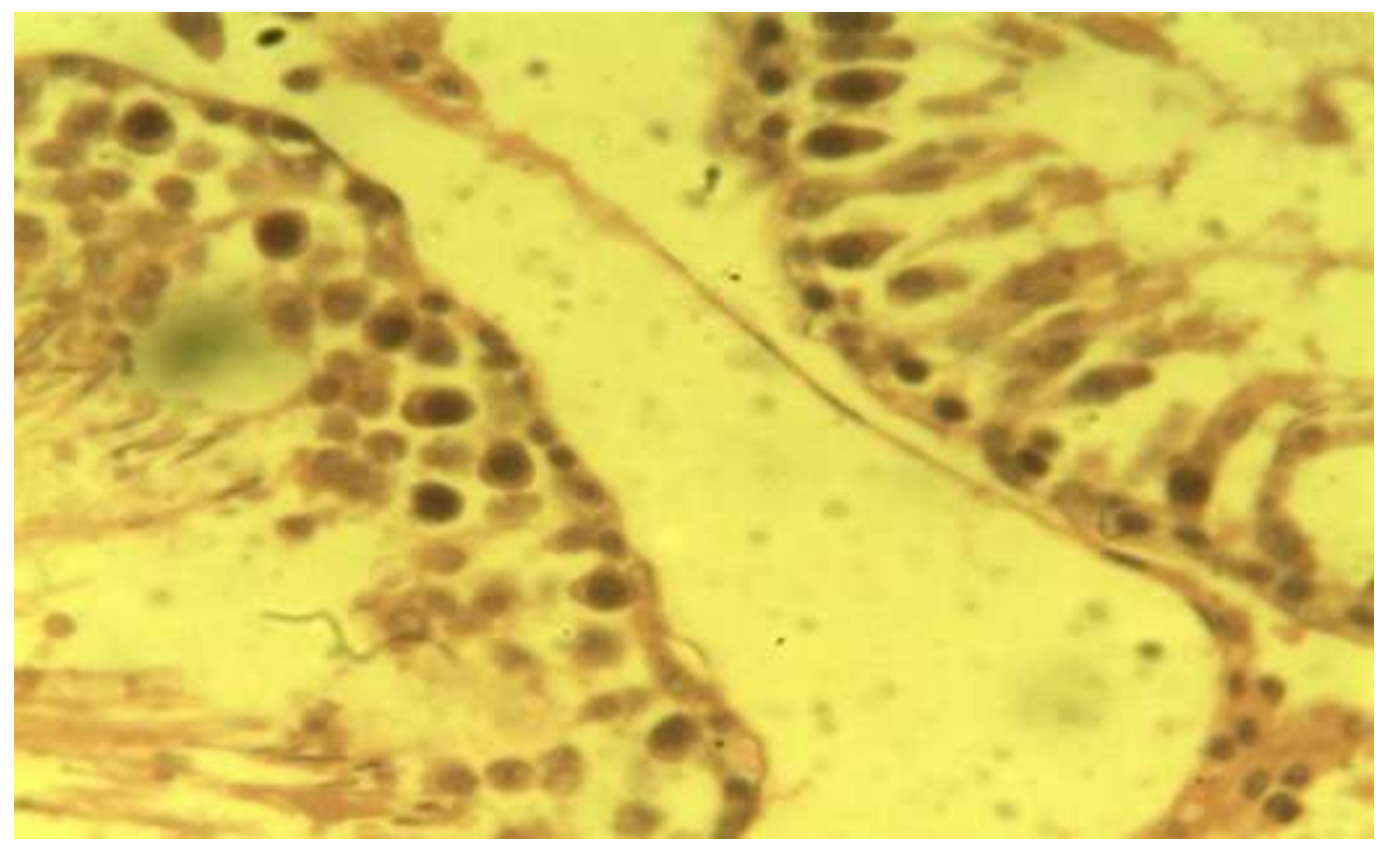

Figure 4 Representative photomicrograph of the testis of group C rats showing presence of intact and normal seminiferous tubules and interstitium with no visible histologic distortions, (X400:H\&E).

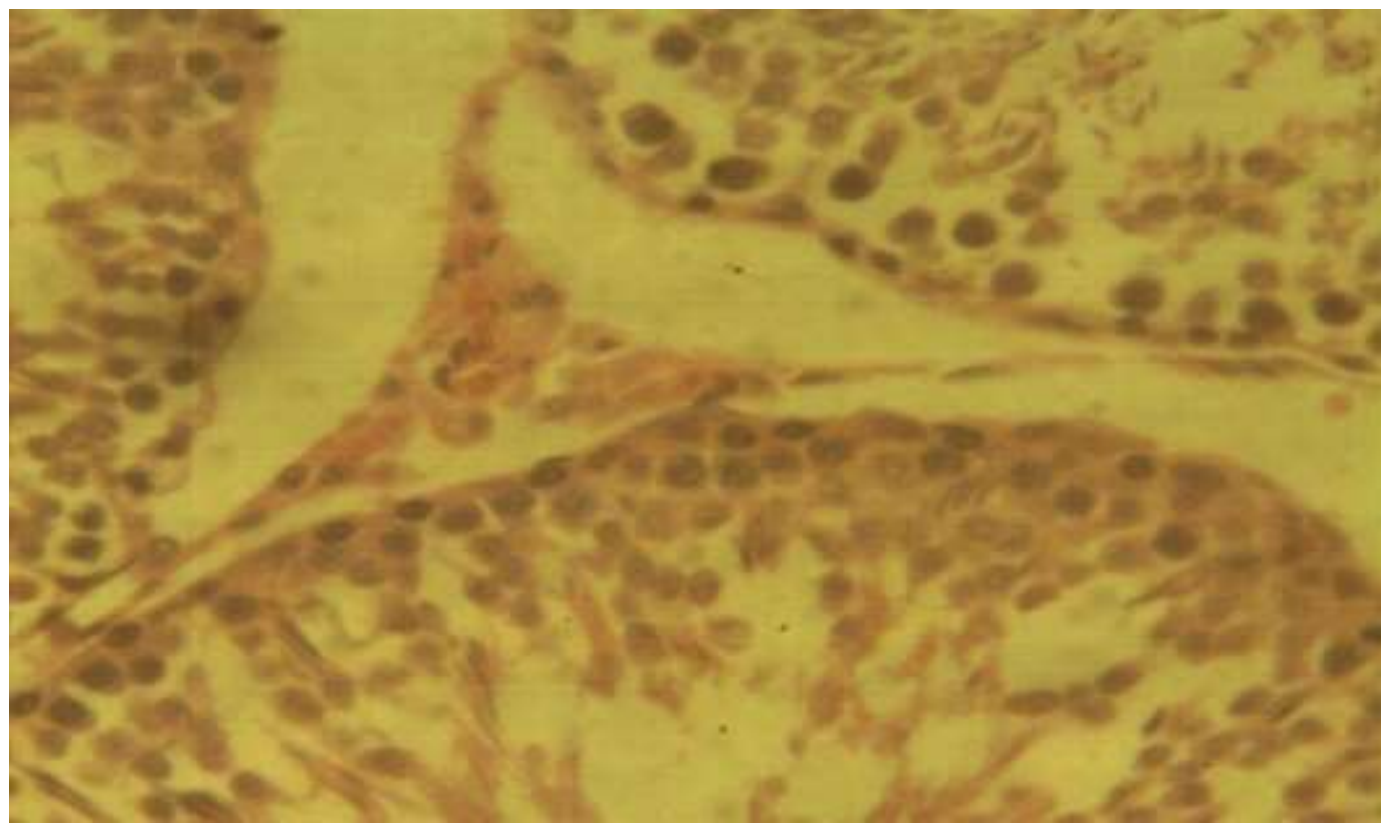

Figure 5 Representative photomicrograph of the testis from group D animals showing normal seminiferous tubules and interstitium containing the leydig cells (X400: H\&E).

\section{Discussion}

The result of this study shows that the Corchorus olitorius leaf extract has a pronounced positive effect on the secretion and blood levels of one of the most important male sex hormones, testosterone. The blood testosterone level of group B (4.10) increased relative to the control group value $(2.50 \mathrm{ng} / \mathrm{ml})$ and that of group C $(4.95 \mathrm{ng} / \mathrm{ml})$ equally increased relative to that of group $\mathrm{B}$ in a manner that appeared to be dose dependent. However, the finding showed that the geometric increase in the blood level of testosterone exhibited by group B over the control group $\mathrm{A}$, and then by group $\mathrm{C}$ over groups $\mathrm{A}$ and $\mathrm{B}$ respectively was halted as the blood testosterone level of the group D animals tottered at 
$4.75 \mathrm{ng} / \mathrm{ml}$ which although still higher than those of groups A and B, but was lower than that of group C. it could therefore be assumed that the maximum effect of Corchorus olitorius leaf extract on blood level was achieved at a concentration of $500 \mathrm{mg} / \mathrm{kg}$ body weight $(1.8 \mathrm{mls})$. This means that if the extract is administered at a concentration higher than $500 \mathrm{mg} / \mathrm{kg}$ body weight, it produces a retrogressive effect on the blood testosterone levels. The general increase in the blood testosterone levels of the animals treated with varying concentrations of the extracts could mean that the extract enhances the mechanism involved in the synthesis of testosterone in the leydig cells of the testis, a finding that contradicts that of Oyedeji et al (2013) [12].

Examination and evaluation of the photomicrographs of the testes of the different animal groups treated with the aqueous leaf extracts of Corchorus olitorius showed that the extract has no effect on the cytoarchitecture of the testis. The seminiferous tubules, and the interstitial components were all seen intact without distortions or degenerative tendencies. Enhancing improved synthesis of testosterone and maintaining a normal testicular histologic features could mean that people, especially males should be encouraged to feed on the plant to achieve an improved fertility status and possibly also, enjoy a general well-being of the reproductive organs, which agrees with the finding of Obembe and Ige (2016)[13].

\section{Conclusion}

The leaf extract of Corchorus olitorius enhances synthesis and secretion of testosterone into the blood, a function that is needed to correct low blood level of testosterone and its consequences. Secondly, the extract appears to maintain the normal cytoarchitectural disposition of the testis.

\section{Compliance with ethical standards}

\section{Acknowledgments}

We sincerely acknowledge the contributions of Mr Sam Offor, the faculty animal house keeper, for the good hygiene in handling of the animals. Mr Shettima, Adamu P. is also acknowledged for typing and editing of the work.

\section{Disclosure of conflict of interest}

Godwin Chinedu Uloneme, Darlington Cypran Akukwu, Damian Nnabuihe Ezejindu, and Chibundu Chiekezi Amadi, declare that there was no conflict of interest.

\section{Statement of ethical approval}

All procedures involved in the handling and sacrificing of the animals conform to the ethical standards and regulations approved by the university animal research committee.

\section{References}

[1] Matsufuji H, Sakai S, Chino M, Goda Y. Relationship between cardiac glycoside contents and color of Corchorus olitorius seeds. Journal of Health Sciences. 2001; 47(2): 89-93.

[2] Tindall HD. Vegetables in the tropics. London: Macmillan press. 1983; 325-379.

[3] Oke OI. Chemical changes in some Nigerian vegetables during growth. Experimental Agriculture. 1968; 4:345349.

[4] Afolayan SO, Igbeka JC, Babalola O. Tillage Systems and their effects on soil properties, crop growth and shoot yield of Corchorus olitorius (Ewedu). Nigerian Journal of Horticultural Science. 2002; 7(1):38-42.

[5] Zakaria ZA, Somchit MN, Zaiton H, Mat-Jais AM, Suleiman MR, Farah W, Nazaratulmawarina, Fatimah CA. The invitro antibacterial activity of Corchorous olitorius extracts. International Journal of Pharmacology. 2006; 2(2):213-215.

[6] Aiyeloja AA, Bello OA. Ethnobotanical potentials of common herbs in Nigeria: A case study of Enugu state. Educ. Res. Rev. 2006; 1(1):16-22.

[7] Osuchukwu IW, Sakpa CL, Ekezie J, Okeke CU, Eke CC, Ezejindu DN. Effect of Leave Extract of Jatropha Tanjorensis on the Testis of Wistar Rats.Journal of Dental and Medical Sciences. 2016; 15(4):66-71. 
[8] Duke JA. Ecosystematic data on economic plants. Quarterly Journal of Crude Drug Reserves. 1979; 17(3-4):91110.

[9] Zakari ZA, Safarul R, Fatimah CA. Influence of temperature on the opoid-mediated antinoceptive activity of Corchorus olitorius in mice. Arch. Pharmacol. 2005; 372:55-62.

[10] Gupta M, Mazumder UK, Pal D, Bhattacharya S, Chakrabarty S. Studies on brain biogenic amines in methanolic extract of Cuscuta reflexa and Corchorus olitorius seed treated mice. Acta. Pol Pharm. 2003; 60:207-210.

[11] Innami S, Ishida H, Nakamura K, Kondo M. Tabata K, Koguchi T, Shimizu J, Furusho T. Jew's mellow leaves (Corchorus olitorius) suppress elevation of postprandial blood glucose levels in rats and humans. International Journal for Vitamin and Nutrition Research. 2005; 75(1):39-46.

[12] Oyedeji KO, Bolarinwa AF, Akinbode AA. Effect of Corchorus olitorius Extract on Reproductive Functions in Male Albino Rats. International Journal of Pharmacy and Pharmaceutical Sciences. 2013; 5(3): 427-431.

[13] Obembe 00, Ige AO. Sperm parameters of Male Wistar Rats Treated with Anacardium occidentale L. leaf extract Research Journal of Health Sciences. 2016; 4(1): 83-89. 